\title{
Children's Stories-Based Character Educationmodel As Strategy Of Self-Control Strengthening
}

\author{
U'um Qomariyah $^{1}$, Qurrota Ayu Neina ${ }^{2}$ \\ \{1uum@mail.unnes.ac.id, neina@mail.unnes.ac.id\} \\ ${ }^{1}$ Department of Indonesian Language and Literature, Faculty of Language and Arts, \\ Universitas Negeri Semarang
}

\begin{abstract}
Literary learning especially in schools has allegedly been untapped properly. The role of literature, especially children's stories as strengthening self-control has not been embraced. Children's stories are limited to mere entertainment. Whereas in the era of the industry 4.0, children's stories have a strategic role in developing character, strengthening liability, and at the same time strengthening students' self-control. This low role causes literary learning in schools not run optimally and as it is. This paper aims to uncover children's stories-based character education model. The children's stories-based character education model that can be implemented by teachers in schools is the model of storytelling, role playing, conversion of literary works, reproduction of literary works, interpretations (searching and interpreting). Strengthening character and increasing self-control will later be used to help children examine themselves and change their personal way of life in order to ensure a sustainable future.
\end{abstract}

Keywords:Learning model, children's story, character, self-control.

\section{Introduction}

Childhood is a critical time for one's psychological development, meaning that the formation of mental and intelligence during childhood is very determining on the character of the child when he grows up. Santrock [1] states that children are interesting figures because in their childhood important developments will occur. However, unfortunately the childhood apparently has not maximally contributed to the development of character and strengthening self-control. This is allegedly because character education by taking advantage of literary works has not yet strategically taken a role. Qomariyah [2] states that literary learning (children's stories) has so far been underestimated.

Yet if examined, stories are very strategic in an effort to strengthen the child's character and self-control. Medress [3] states that the children literature(stories) benefits for education are precisely felt in their role in carrying values and lessons explicitly or implicitly, including in efforts to achieve self-control both now and later in adulthood. This then reinforces the importance of children's stories as part of efforts to shape mental, character, and selfdevelopment of children. As for the achievement of self-control, children's stories can be used to help children examine themselves and change their personal way of life in order to ensure a 
sustainable future, to identify, investigate, evaluate, and take appropriate actions to maintain, preserve, and develop mental and self-character, environment, and society [3-5]. Stories serve as a bridge in providing opportunities for children to start life in the beginning with the surrounding environment and the wider world. As we all know, there are many cases of abuse of the role and function of children due to the child's unconscious of the dangers. On the one hand, the rise of technology and information gives a central role to children's behavior, even exceeding the central role of parents in the family and teachers in schools. Some cases of concern include the involvement of children in drug abuse, cases of bullying between friends, even cases of male and female relationships that exceed the limits of reasonableness (sexual harassment). Not to mention other moral cases such as students who no longer respect their teachers, children who commit crimes against family or friends, traffic violations, destruction of public infrastructure, inappropriate expressions of words, and many other cases that are actually very unethical if done by children. Similar cases are also experienced by many Indonesian youth. These cases give the impression that the lack of self-control of a child will result in wrong character patterns. Due to the lack of inherent aspectsofcharacter in students as well as self-control strengthening, we need a meaningful strategy to overcome this. In this case the learning of children's stories becomes one of the strategic alternatives as character education and improving children's self-control. Children's story-based learning was chosen because it has mental and spiritual strength to integrate all aspects of children's knowledge and to significantly and sustainably internalize the aspects of character building.

Sayuti[6]reinforces that literary learning that is able to present creativity through meaningmaking processes in learning is expected to encourage the learning community to maintain traditional values, cultural identity, and the accumulation of local knowledge that is expected to grow, develop, and interact with intake energy from external sources. It can be said that children's stories have a positive impact because at the same time, the child experiences high imagination and fantasy development, regardless of whether the story is considered reasonable or not. The fact that children's stories have not been touched in elementary schools is proven by the study of literature at the next level which has not yet shown as an encouraging. Based on research findings, the low student interest in learning at the college level is allegedly due to the literature learning process at the previous level (elementary, junior, senior high school) considered low and unsatisfactory[7-12]. Teachers are considered to have a big hand in creating a gap between literature and students. As a result, most students become antipathy with literature and everything related to literary works.

Basically, literary learning is necessary to be taught in schools[13-16]. Many things that underlie these reasons include literary works being a bridge of connection between reality and fiction. Moreover, there is a tendency for human to prefer the relationship between reality and fiction. This tendency impulsively will encourage human to carry out activities without being ordered. It is expected that good encouragement in literary works will encourage readers, in this case students will do good things too. In the end, character education as an important bridge in printing the golden generation, will be achieved.

\section{Research Method}

In accordance with the objectives of this study, the approach used in describing children's stories-based character education model is descriptive qualitative. This approach is used to obtain a more detailed and clear picture of the characteristics of children's stories as a strategy 
of strengthening self control. Studying the characteristics and models (forms) means it involves talking about something that exists in the human mind. To know these thoughts, indicators used are in the form of words, phrases or sentences. For reasons as described, the approach used is a qualitative approach. The source of the data in this study consists of two things, namely the characteristics of children's stories-based character education and children's stories-based character education model.

When collecting the data, the researchers collected data by interviewing elementary students and teachers, observation, and literature research. Interviews, observation, and library research were based on research objectives which are used to uncover and answer the research problems. In the next stage, which is the data classification stage, data sorting and selection were carried out in accordance with the importance of the issues discussed in this study. In the analysis and interpretation of data, the analysis of data which had been determined using a qualitative descriptive approach was carried out. Then generalization and conclusion were made with regard to the results of the analysis and interpretation of the data. Finally, a research report was arranged by following the standard of arranging a scientific report that has been set as the evidence of this conducted research.

Specifically, the data analysis technique used in this study is an interactive analysis model as proposed by Miles and Huberman[17], which includes stages: (1) data collection, (2) data reduction, namely reducing (discarding) data which are irrelevant for research purposes, (3) data display, in the form of classification, showing, description, division, etc., and (4) conclusion or verification of data and results. Based on the above details, this research is focused on knowing the characteristics and model of children's stories-based character education as a reinforcement of children's self control.

\section{Result and iscussion}

\subsection{Characteristics Of Children's Stories-Based Character Building}

The basic material of literature is language. Language is a sign system used by the community. The sign is meaningful and agreed upon by the community. According to Teeuw[18] in the sign system available conceptual device that is difficult to avoid because it is the basis of real-world understanding and at the same time is the basis of communication between members of the community.

Therefore, in relation to language in children's stories, there are several distinguishing criteria although the differencesis not something that is absolute nature. Some language criteria in children's stories are described as follows.

First, language used in children's stories is simple. Children's language is more likely to use straightforward words rather than figurative. Children do not like language that is confusing or creates a very high imagination so that too hard to be understood. Second, the emphasis is more on content, while language is as a supporting device. If in adult literary works, language is more likely to be emphasized on symbolism, but not in children's stories. Symbols that are sometimes irregular are intentionally not given by the writer so that children do not get bored because they cannot digest. Third, in general (although this is also one of the limitations of Indonesian children's stories) moral and spiritual values are clearly explained. This characteristic distinguishes children's literature from adult literature. Character values become the foundation of adult writers if they are going to create children's literary works. 
In conclusion, in terms of language especially when related to the speech, children's stories are directed at storytelling techniques that refer to the choice of words, the use of language styles, and the techniques in portraying the character and story settings. For the choice of words is adjusted to the readness of children, namely by using concrete words and language styles in accordance with cognitive development and more refers to explicit understanding. In principle, the way of speaking can be presented reportatively, descriptively, narratively, or directly.

As for the structure of the story, one of them is seen in the aspect of characters and characterizations. Children's stories generally feature not too many characters. It is intended so as not to confuse children in understanding the plot of the story that is illustrated through a series of events. The characterization is carried out firmly and clearly (directly) which also portray the character's nature along with obvious physical description, while the setting of children's stories should describe the places which draw their interest.

Furthermore, in terms of plot, children's stories contain a plot that is linear and centered on one story as not to confuse children. Themes of Children's reading are usually in accordance with their interests, for example about family, friends, mystery, adventure, fantasy, funny stories, fable stories, heroic stories, and so on.

The characteristics above illustrate that children's stories have a different type from adult work. Even so, the obvious difference between children's and adult stories is still a hot debate. It's all due to the overlapping boundaries of the categories of writers and readers of both works that can clearly replace each other. However, if it is connected with the context of learning, then the boundary must be presented clearly in an effort to strengthen character and instill moral values.

\subsection{Children's Stories-Based Character Education Model}

The following will be explained about the children's stories-based character education model as a strategy to strengthen self-control.

\subsubsection{Storytelling Model}

Storytelling is a model that is commonly practiced by the public. In Indonesian, it is called mendongeng. The storytelling model is considered as an art activity that involves stories, namely narrative plots that are adapted from the real and imaginative events taken from various oral and written sources. This model involves the audience or viewers directly or indirectly. Generally the audience will feel and go along with the flow of the story. That is why this model involves the ability of a storyteller to give life to a story through language, gestures, and vocalizations, both by singing and using musical instruments or other supporting tools.Through the description above, storytelling (mendongeng) is an art in telling a story with the purpose to entertain a live audience (direct viewers) about real or imaginative events that can be taken from poetic texts and / or prose and other sources (oral, written or recorded) which involve gestures, vocalizations, music, or pictures to give life to the story.

\subsubsection{Role Playing Model}

Playing is an activity that will naturally be loved by children. Therefore, transforming learning into a game will certainly be a special attraction for a child. Teaching children's stories with role playing techniques that is a teaching and learning process by involving children to portray the characters depicted in literary works. It is commonly known as role playing or play learning.

By playing roles, children are expected to be able to appreciate literary works through the character portrayal contained in literary works. Through role playing, children will get 
emotional and aesthetic experiences which can support the development of children's emotional intelligence. Thus, children will be led to learn in being more attractive, expressive, humane, and have character.

\subsubsection{Literary Works Conversion Model}

The conversion model is usually interpreted as reinventing or re-creating literary works. The conversion model is to change the literary work which recreates the work sourced from a creator into a literary work in another form so that a new form of works are produced. For instance, a form of prose is changed into poetry or poems are made into songs.

The conversion model in children's literature teaching aims to actively involve children in the learning process. This model is considered effective in developing children's creativity in creating literary works. The model involves children to cooperate, contribute suggestions, and solve problems in the making of works. Through this model, children will be able to develop their creativity, critical thinking, and develop their imagination. This model can be done individually or in groups. On the other hand, the child's psychological readiness is also needed to be considered.

\subsubsection{Literary Works Reproduction Model}

The reproduction model is an activity to produce literary works. This model gives freedom to children to express their feelings, ideas, responses, and imagination through a sequence of words, both in the form of stories (prose) and poetry.

This model has the benefit of giving children the freedom to express their ideas and feelings, the children will understand and experiences the creative process of a story writer or author, and they will also have their own language style in expressing their ideas. This model is performed to train children to imagine, practice interpreting other people's feelings, and follow the thoughts of others.

The advantage of this model is that children's creativity is appreciated. Of course, this will be interesting learning for children. The teacher can develop this model with the technique of stringing words. If done in groups, it can be done with the first stage, where one of the students starts by writing a line at the beginning or if possible one point of thought (one paragraph). Then, after the first student is finished, the second students will continue by considering the unity of ideas.

\subsubsection{Interpretation Model (Searching and Interpreting)}

The interpretation model is basically a search for meaning. In relation to the teaching of literature, students in particular classes do not make interpretations that are too complicated, but rather simple interpretations of the story being read. It means that the interpretation is adjusted with the development of children's psychology. This search will make students able to examine and find the meaning contained in the literary works they read. If they have got the meaning, it is expected that the moral message contained in a literary work will be taken and applied in everyday life. Of course, this requires guidance from the teacher.

As an interpretation model, the experience of reading becomes something important. However, reading has a relatively broad understanding. It is because reading activities can be seen from various sides, namely the purpose, the process of the activity, the object of reading, and the media used. 


\section{Conclusion}

Based on the results and discussions from the problem statements in the previous chapter, this study concludes two things as follows. Children's stories as part of children's fiction have different characteristics compared to adult fiction. These characteristics can be seen from the form of presentation, the language used (how it is presented), and the structure of the story (plot, characters with the characterizations, and themes). The children's stories-based character education model for strengthening self-control that can be utilized namely; storytelling, role playing, literary works conversion, literary works reproduction, interpretation (searching and interpreting).

\section{References}

[1] Santrock JW. Life Span Development (Perkembangan Masa Hidup). Jakarta: Erlangga; 2002.

[2] Qomariyah U. Model Pembelajaran Apresiasi Prosa Berbasis Kisah Inspiratif Tokoh Sebagai Upaya Pembentukan Karakter Mahaanak. Transform J Bahasa, Sastra, dan Pengajarannya. 2(1):23-35.

[3] Medress A. Storybooks: A Teaching Tool for Sustainability [Internet]. Available from: http://digitalcollections.sit.edu/cgi/viewcontent.cgi?article=1057\&context=isp_collection

[4] Bradbery D. Teaching for Sustainability Using Children's Literature to Develop Understandings of Ecological Sustainability. In: Preceedings of the 7th Congress WEEC. Marocco;

[5] Boudreaux B. The Representation of The Environment in Children's Literature [Internet]. University of New Orleans; $2006 . \quad$ Available from: http://scholarworks.uno.edu/cgi.viewcontent.cgi?article:1368\&context=td

[6] Sayuti SA. Pengajaran Sastra danKearifanLokal. In: Seminar Internasional dalam Rangka PIBSI XXXV. Universitas Jenderal Soedirman Purwokerto;

[7] Nurgiyantoro B. Sastra Anak: Pengantar Pemahaman Dunia Anak. Yogyakarta: Gadjah Mada University Press; 2005.

[8] Sayuti SA. Pengantar Pengajaran Puisi. In: Jabrohim, editor. Pengajaran Sastra. Yogyakarta: Pustaka Pelajar; 1994.

[9] Endraswara S. Metodologi penelitian Sastra Epistemologi Model Teori dan Aplikasi. Yogyakarta: Pustaka Widyatama; 2003.

[10] Suharianto. Sastra dan Pengajarannya. In: Seminar Nasional Rekonstruksi Pengajaran Sastra. Universitas Negeri Semarang;

[11] Sudikan SY. Pembelajaran Sastra yang Apresiatif dan Pembangunan Kemandirian Bangsa. In: Seminar Nasional Rekonstruksi Pengajaran Sastra. Universitas Negeri Semarang;

[12] Sugihastuti. Teori dan Apresiasi Sastra. Yogyakarta: Pustaka Pelajar; 2002.

[13] Norton D. Through the Eyes of a Child: An Introduction to Children's Literature. 2nd ed. Colombus- Ohio: Merril Publishing Company; 1987.

[14] Huck CS, Hepler S, Hickman J. Children's Literature. New York: Holt, Rinehart and Winston, Inc; 1987.

[15] Wray D, Medwell J. Literacy and Language in the Primary Years. London and New York: Routledge; 1991.

[16] Alwasilah AC. Kurikulum Berbasis Sastra. In: Seminar Nasional Kondisi Bahasa Indonesia Masa Kini. Jakarta; 2006.

[17] Miles MB, Huberman AM. Analisis Data Kualitatif. Jakarta: UI Press; 2009.

[18] A. T. Sastra danIlmu Sastra. Jakarta: Dunia Pustaka Jaya; 2003. 